\title{
IDENTIFICATION OF PLANT SPECIES FOR POLLINATOR RESTORATION IN THE NORTHERN PRAIRIES
}

\author{
Diana B. Robson ${ }^{1, *}$, Cary Hamel² and Rebekah Neufeld ${ }^{3}$

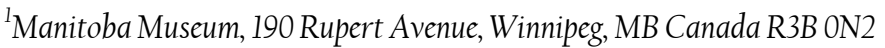 \\ ${ }^{2}$ Nature Conservancy of Manitoba, 611 Corydon Ave., Winnipeg, MB, Canada, R3L OP3 \\ ${ }^{3}$ Nature Conservancy of Manitoba, 207-1570 18th Street, Brandon, MB, Canada R7A 5C5
}

\begin{abstract}
Research on diurnal plant-pollinator interactions indicates that a small number of generalist plants provide a disproportionately high amount of floral resources to pollinating insects. Identifying these generalist plants would help prairie restoration specialists select species that will provide forage for the majority of pollinator taxa. Field research in three Canadian fescue (Festuca hallii) prairie preserves that were at most $3.3 \mathrm{~km}$ away from each other was conducted in 2014 and 2015 to create pooled, weighted, plant-insect visitor matrices for each site. Using these matrices, generalization $(\mathrm{G})$ scores were calculated for each plant species to help assess their importance to wild insect visitors as this method controls for differences in insect abundances over the year. The three species with the highest average generalization scores were Solidago rigida, Erigeron glabellus and Symphyotrichum laeve. Species accumulation curves were created to determine how many plant species would need to be present before most pollinator taxa would have at least one acceptable forage species. This research indicates that the 16 plant species ( $33 \%$ of the total) with the highest average generalization scores were visited by $90 \%$ of the observed pollinator taxa. To detect exceptionally attractive plant species while accounting for natural differences in abundance, we calculated the insect, bee and fly visitation rates per inflorescence. There was several specialized plant species that were visited frequently by bees. Most of these specialized plants had purple or yellow, tubular flowers, and bloomed in mid to late summer when bee populations were most numerous.
\end{abstract}

Keywords: Fescue prairie, generalists, insect visitors, pollination, restoration, seed mix

\section{INTRODUCTION}

Fescue prairie is a unique North American grassland formation dominated by Festuca hallii (Coupland \& Brayshaw 1953; Coupland 196I). Interest in conserving and restoring Canada's fescue prairies is increasing due to the relative rarity of this ecosystem; agricultural conversion, industrial activity and exotic species encroachment have drastically reduced the amount of native prairie remaining. Complete restoration of all species that were native to an ecosystem is the ideal end goal as literature suggests that the more species present, the greater the resiliency of the community (LaBar et al. 20I4). Due to the short growing season and potential for both late spring and early fall frosts in the northern prairies, using locally-adapted seeds is recommended to avoid phenological mismatching (Chuine 2010). Currently, the seeds of native grasses are the ones most commonly available from commercial seed growers in western Canada. Unfortunately, grasses are less important to pollinators than plants that offer large amounts of nectar. The addition of insect-pollinated herbs or shrubs to seed mixes is needed to ensure that pollinators will be attracted to restored areas (Menz et al. 20II). Some plants may be exceptionally attractive to pollinators; research is needed to identify them.

Received I6 January 2017, accepted I2 September 2017

*Corresponding author: drobson@manitobamuseum.ca
Research on plant-pollinator interactions has found that some plants are super-generalists that act as the skeleton of an ecosystem (Jordano et al. 2003; Bascompte \& Jordano 2007). Essentially, super-generalists enable less common species to persist (Memmott et al. 2004; Saavedra et al. 20II). Usually these super-generalist plants are visited by a wide diversity of insect taxa due to their large floral displays, radially symmetrical flowers and easily accessible nectar (Elle et al. 20I2; Koski et al. 2015). Ecological theory suggests that including super-generalist plants in a seed mix will result in a more diverse and stable plant-pollinator community than adding species at random (Montoya et al. 2012; LaBar et al. 2014; Harmon-Threatt \& Hendrix 2015). As a result, plant-pollinator interaction matrices are increasingly being used to help identify the most important plants for restoration purposes (Forup et al. 2008; Devoto et al. 2012; Montoya et al. 2012; Russo et al. 2013). Indeed, including the most generalized plants to restoration seed mixes does increase pollinating insect diversity and abundance over randomly chosen mixes (LaBar et al. 20I4; Kremen \& M'Gonigle 2015; M'Gonigle et al. 2015).

Following Isaacs et al. (2009) note that regional research efforts are needed to identify the best native plant species to support the pollinator communities in each region, the goal of this study was to identify plant species most attractive to pollinators to use for restoration of Canada's fescue prairies. To conduct our evaluation we collected plant-pollinator interaction data from three fescue prairie preserves in south 
western Manitoba during the summers of 2014 and 2015. To identify the super-generalist plant species, and make it easier to compare species with a different number of available insect pollinators, we calculated a generalization score (G) for each species developed by Medan et al. (2006). This generalization score takes into account not just the number of insect-visiting taxa $(\mathrm{S})$, but their resource usage (RU) (i.e. the proportion of all available insect taxa that visit the plant), and evenness (E). Plants with high generalization scores are visited equally by a large number of the available insect taxa compared to plants with low generalization scores, which tend to be visited by only a few insect taxa and thus are more specialized. We identified the species with the highest generalization scores in these fescue prairies and considered them to be top candidates for inclusion in fescue prairie seed mixes. However, Harmon-Threatt and Hendrix (2015) and Russo et al. (2013) noted that there are certain specialist plants (often legumes) that are visited very frequently by bees and may be important to include in a seed mix to support these insects. Further, it is possible that plant density will affect the $G$ score simply by increasing the likeliness that an encounter will be observed or that insects will visit that plant species. Therefore, we also determined the visitation rate per inflorescence (instead of the rate per plot) by all the pollinators, by just bee taxa, and by just fly taxa. We created species accumulation curves (Ebeling et al. 2008) to help determine how many of the most generalized plants would have to be added to a seed mix before most insect taxa $(90 \%)$ had at least one plant species to forage on. Lastly, we graphed the phenology of all plant species observed to determine the flowering sequence and detect any gaps.

\section{MATERIALS AND METHODS}

\section{Study Sites}

Three prairie conservation sites in the Aspen Parkland Ecoregion south of Riding Mountain National Park, Manitoba were surveyed: Elk Glen $\left(50.849444^{\circ} \mathrm{N}\right.$, $\left.100.819417^{\circ} \mathrm{W}\right)$, Cleland $\left(50.830693^{\circ} \mathrm{N}, 100.788083^{\circ} \mathrm{W}\right)$ and Crown $\left(50.834333^{\circ} \mathrm{N}, 100.787750^{\circ} \mathrm{W}\right)$. The plots at Elk Glen were 2.8 to $3.3 \mathrm{~km}$ away from the plots at the Cleland and Crown sites; plots at the latter two sites were all within $600 \mathrm{~m}$ of each other. The soils in this area are moderately calcareous consisting of mainly sand and silt derived from glacial till. The sites contain mainly mixed wood forests with some fescue prairie patches; past grazing practices are thought to have reduced the fescue grass component in the Riding Mountain region (Trottier I986). As the prairies nearest the roads were heavily invaded by non-native species such as Bromus inermis and Poa pratensis, our choices regarding plot locations were limited to areas that were accessible only by foot, which constrained the number of plots that could be surveyed in a day. There are at least I55 vascular plant species that occur in the area, but many of these species are found in the wetlands or forested parts of the sites. The close proximity of the sites means that the climate and landscapes were similar. The Elk Glen and Cleland sites are owned and managed as nature preserves by the Nature Conservancy of Canada (NCC) but both were previously grazed by cattle, the latter as recently as 2013 . The Crown land is managed by the Manitoba government for wildlife and agricultural values and may have been historically grazed by cattle several decades ago. As there were some differences in the plant communities due to their grazing history, they were all considered separate sampling sites.

\section{Vegetation Surveys}

In 20I4, we established six $4 \mathrm{~m}^{2}$ permanent plots in each of the three sites on flat to gently sloping land. Small plots rather than transects were chosen to enable: (I) future comparison of these data with other Manitoba timed pollinator surveys in tall-grass prairie (Robson 2008, 2013), (2) observations of interactions between less common plants and insects (Gibson et al. 20II), and (3) calculation of visits/inflorescence in a reliable way. The plots were randomly selected and at least $10 \mathrm{~m}$ apart. In 20I4, sampling was conducted for four consecutive days per site, which was repeated four times in mid-June, -July, -August and September (I6 days total). In 2015, sampling was conducted on the previously established plots for four consecutive days per site, repeated four times at the beginning and at the end of June, in early July and in late August (I6 days total). In total I5 more plant species were observed in 2015 than in 2014 as a result of conducting the surveys on different calendar days. Plant richness and number of inflorescences of each species in the plots was recorded each sampling day.

\section{Floral Visitor Surveys}

Flower-visiting insect sampling occurred on the same days and in the same plots as the vegetation surveys: four consecutive days for four months in each of 2014 and 2015 for a total of 32 days. Each plot was surveyed for 10 minutes each sampling day thus the total time spent surveying was 96 hrs. Due to natural variability in abundance, some plant species were present in more plots than others and thus were observed for a longer period of time. Surveys were conducted between 09:30 and 17:00 when insect foraging activity is at a maximum (Kevan \& Baker 1983) thus nocturnal insects were not observed. During the survey periods the mean temperature recorded at the nearest Environment Canada weather station (i.e. Brandon, $\mathrm{MB}$ ) was $17.7^{\circ} \mathrm{C}( \pm 0.9 \mathrm{SE})$, the mean relative humidity $53.0 \%( \pm$ I.9 SE) and the mean wind speed $10.0 \mathrm{~km} / \mathrm{hr}( \pm 0.62 \mathrm{SE})$. The order in which the plots were visited was randomized each day. Some of the flower-visiting insects (e.g. crabronid wasps in the genus Ectemnius) may have been predators of other flower-visiting insects. Regardless of whether the wasps were foraging for pollen, nectar or prey, they were considered potential pollinators and their visitations recorded. Ambush bugs (Phymata spp.) and crab spider (Misumena spp.) visits were not recorded as they remain stationary on one inflorescence for a long time and thus were unlikely to act as pollinators.

All insect visitations to any inflorescence in the plot were recorded but the quality of the visit was not assessed and therefore may not have resulted in pollination of the plant. However, even if an insect visit did not fulfill the reproductive goal of the plant, the plant was probably important for the insect's survival; this is an aspect of plant- 
pollinator interaction that we wanted to capture. The first time an insect taxon was observed a specimen was obtained and given a unique collection number. When the same (or what appeared to be a very similar) taxon was observed later on, the collection number was used to link that insect visit to the plant. Although this technique does not allow for complete identification "on the wing" (resulting in an underestimate of insect taxa) it does enable evaluation of insect visitation frequency, which was then used to determine the visitation rate for each plant species by all insect taxa, by bees only and by flies only (Parachnowitsch \& Elle 2005). All insect voucher specimens were identified by zoologists using reference specimens at the Manitoba Museum (MM) and the Wallis Roughley Entomology Museum in Winnipeg, Manitoba; the specimens were deposited in MM's zoology collection.

\section{Data Analysis}

The daily inflorescence density at each site was calculated by counting the number of inflorescences of each species in each plot, dividing by the plot area $\left(4 \mathrm{~m}^{2}\right)$ and averaging the values of all plots. The average inflorescence density at all three sites over the length of the study ( 32 days) for each species was then calculated. Using the density data we created a phenology graph. To do this, we determined the calendar day (from pooled 2014 and 2015 data) when each plant species began and ceased blooming in our plots. Differences in flowering times from year to year are known to vary in this region due to differences in snow cover, spring temperatures and late frosts, thus bloom times should only be considered approximate. Further, as we did not conduct the surveys every single day, the length of the flowering period is likely slightly longer than indicated.

For each of the three sites the data were used to create two year cumulative, weighted (i.e. by the number of visits recorded) plant-insect visitor matrices. These matrices were used to calculate a generalization $(\mathrm{G})$ score (Medan et al. 2006) for each plant species using pooled data over two years (Appendix I) to facilitate comparison between them as:

$$
\mathrm{G}=\mathrm{RU} \times \mathrm{E}
$$

Where

RU (Resource use) is:

$$
R U=\frac{\# \text { of visiting insect taxa }}{\# \text { of available insect taxa }}
$$

$\mathrm{E}$ (evenness) is:

$$
E=\frac{-\sum_{i} p_{i} \cdot \ln p_{i}}{\ln S}
$$

where $p i$ is the proportion of all interactions corresponding to the $i$ th individual visiting insect of a given plant, and $S$ is the total number of individual insects visiting it. When evenness is maximal, $E$ is equal to $I$ and when it approaches 0 , interaction frequencies are very unequal. When a plant had only one insect visitor, the index could not be computed because it required dividing by zero; these plants were excluded from the analysis. The available insect taxa were all the taxa observed at that site at any time over the two year study. The $G$ scores from each site were then averaged to get a single $G$ score for each plant species. Although pooling the data over two years obscures some of the variation, we believe the results reflect the core of the most common insect visitors and interactions in this area. When a plant flowered at more than one site, the overall G score was the average of all the scores. The G, RU and E scores varied between 0 and I. Low $G$ scores indicated specialists while higher ones indicated generalists. All plants were ranked according to their $G$ scores. If two species had the same $G$ score, the plant that was visited at a higher rate by all insects was listed first. We then graphed species accumulation curves using Microsoft Excel where the plants were arranged in decreasing order of their G scores. The cumulative number of insect taxa that visited the accumulative number of plant species was determined using the matrix data. These data were used to determine the minimum number of plant species that would need to be added to an ecosystem to ensure that most ( $\sim 90 \%)$ insect taxa had at least one preferred forage plant species.

The density of each plant species at the sites was different, which obscured evaluation of their importance to the insect visitors. To address this, we calculated the insect visitation rate per inflorescence to reduce the chance that density was affecting the results. The visitation rates are the averages over the number of days the plant was in flower. We also calculated the bee and fly visitation rates per inflorescence to determine which plant species were particularly attractive to them. We used linear regression analysis to determine the relationship between plant density and $\mathrm{G}$, and plant density and insect visitation rate per inflorescence by all insects, by bees only and by flies only. Logarithmic transformations to homogenize variances were applied to the data. These statistical tests were performed using Analyze-it software (Analyze-it Software Ltd. 2009). The percentage of all visits each insect taxon made at each site was determined using pooled data from 2014 and 2015, and then averaged when the taxon occurred at more than one site. Lastly, we obtained lists of species available from local Canadian seed suppliers to determine which plants are currently available for use in restorations.

\section{RESULTS}

During the study, a total of IIO insect taxa were observed visiting the flowers of 48 forbs and/or shrubs found within the study plots (Appendix II). The average generalization score of all 48 plant species was 0.07 with the highest value 0.19 and the lowest 0.0I (Tab. I). Solidago rigida had the highest $G$ score and received the greatest number of insect visitor taxa (38). Erigeron glabellus has the second highest $\mathrm{G}$ score even though it was visited by fewer insect taxa than Symphyotrichum laeve and Solidago nemoralis due to a greater evenness. Three of the species with the highest $\mathrm{G}$ scores also had high insect visitation rates per inflorescence: Solidago rigida, $S$. canadensis and Symphyotrichum laeve. Solidago rigida and Symphyotrichum laeve were also visited frequently by bees. However, many of the plant species with the highest visitation rates had relatively low $G$ scores $(\leq 0.06)$ including: Cirsium 
TABLE I. Average generalization scores $(G)$, insect visitation rates, number of insect visitor taxa (S), and inflorescence (infl.) density and flowering period data for vascular plant species in three fescue prairie sites in southern Manitoba (sorted by G score then insect visitation rate). Plant species with only one insect visitor were excluded. Numbers in bold are the ten highest values for that variable.

\begin{tabular}{|c|c|c|c|c|c|c|c|}
\hline Scientific name & $\begin{array}{l}\mathrm{G}(\text { mean } \\
\pm \mathrm{SE})^{\mathrm{I}}\end{array}$ & $\begin{array}{l}\text { Insect }^{2} \\
\text { visitation rate } \\
\text { (mean visits } \\
\text { infl. }^{-1} \text { day } \\
{ }^{1} \pm \mathrm{SE} \text { ) }\end{array}$ & $\begin{array}{l}\mathrm{Bee}^{3} \text { visitation } \\
\text { rate (mean } \\
\text { visits infl.- } \\
{ }^{\mathrm{I}} \mathrm{day}^{-1} \pm \mathrm{SE} \text { ) }\end{array}$ & $\begin{array}{l}\text { Diptera } \\
\text { visitation rate } \\
\text { (mean visits } \\
\text { infl. }^{-1} \text { day } \\
{ }^{\mathrm{I}} \pm \mathrm{SE} \text { ) }\end{array}$ & $\begin{array}{l}\text { S (total \# } \\
\text { of insect } \\
\text { visitor } \\
\text { taxa) }\end{array}$ & $\begin{array}{l}\text { Infl. density } \\
\text { (mean } \\
\left.\# / \mathrm{m}^{2} \pm \mathrm{SE}\right)\end{array}$ & $\begin{array}{l}\text { Flowering } \\
\text { period }^{4}\end{array}$ \\
\hline Solidago rigida & $0.19 \pm 0.03$ & $0.50 \pm 0.1 \mathrm{I}$ & $0.35 \pm 0.08$ & $0.13 \pm 0.04$ & 38 & $0.34 \pm 0 . \mathrm{II}$ & M-L \\
\hline Erigeron glabellus & $0.15 \pm 0.06$ & $0.19 \pm 0.07$ & $0.07 \pm 0.02$ & $0.09 \pm 0.05$ & 22 & $0.16 \pm 0.04$ & E-M-L \\
\hline Symphyotrichum laeve & $0.14 \pm 0.01$ & $0.4 \mathrm{I} \pm 0.09$ & $0.30 \pm 0.08$ & $0.10 \pm 0.03$ & $3 I$ & $0.4 \mathrm{I} \pm 0 . \mathrm{II}$ & $\mathrm{L}$ \\
\hline Solidago nemoralis & $0.14 \pm 0.08$ & $0.23 \pm 0.09$ & $0.14 \pm 0.06$ & $0.08 \pm 0.04$ & 32 & $0.5 \mathrm{I} \pm 0 . \mathrm{I} 4$ & M-L \\
\hline Linum lewisii & $0.14 \pm 0.0$ & $0.19 \pm 0.08$ & $0.08 \pm 0.04$ & $0.03 \pm 0.02$ & I I & $0.07 \pm 0.02$ & E-M \\
\hline Solidago canadensis & $0.12 \pm 0.0 \mathrm{I}$ & $0.3 \mathrm{I} \pm 0.09$ & $0.14 \pm 0.05$ & $0.09 \pm 0.04$ & 19 & $0.05 \pm 0.02$ & $\mathrm{~L}$ \\
\hline $\begin{array}{l}\text { Campanula } \\
\text { rotundifolia }\end{array}$ & $0.12 \pm 0.04$ & $0.07 \pm 0.01$ & $0.06 \pm 0.01$ & $0.0 \pm 0.0$ & 20 & $0.36 \pm 0.10$ & M-L \\
\hline Achillea millefolium & $0.12 \pm 0.02$ & $0.06 \pm 0.01$ & $0.02 \pm 0.01$ & $0.04 \pm 0.01$ & 20 & $0.32 \pm 0.08$ & E-M-L \\
\hline $\begin{array}{l}\text { Symphoricarpos } \\
\text { occidentalis }\end{array}$ & $0.12 \pm 0.03$ & $0.03 \pm 0.02$ & $0.0 \mathrm{I} \pm 0.0 \mathrm{I}$ & $0.02 \pm 0.02$ & 26 & $0.29 \pm 0.09$ & M-L \\
\hline $\begin{array}{l}\text { Apocynum } \\
\text { androsaemifolium }\end{array}$ & $0.10 \pm 0.0$ & $0.20 \pm 0.10$ & $0.09 \pm 0.04$ & $0.07 \pm 0.05$ & 7 & $0.03 \pm 0.01$ & $\mathrm{M}$ \\
\hline Astragalus laxmannii & $0.10 \pm 0.04$ & $0.09 \pm 0.06$ & $0.07 \pm 0.06$ & $0.0 \pm 0.0$ & $\mathrm{I} 4$ & $0.36 \pm 0.14$ & M \\
\hline Prunus virginiana & $0.09 \pm 0.0$ & $0.50 \pm 0.29$ & $0.40 \pm 0.3 \mathrm{I}$ & $0.04 \pm 0.02$ & 9 & $0.07 \pm 0.03$ & E \\
\hline Drymocallis arguta & $0.09 \pm 0.03$ & $0.23 \pm 0.05$ & $0.18 \pm 0.05$ & $0.02 \pm 0.01$ & $\mathrm{I} 8$ & $0.12 \pm 0.03$ & M \\
\hline Rudbeckia hirta & $0.09 \pm 0.03$ & $0.22 \pm 0.06$ & $0.06 \pm 0.04$ & $0.16 \pm 0.06$ & 18 & $0.12 \pm 0.03$ & M-L \\
\hline Lathyrus venosus & $0.09 \pm 0.0$ & $0.12 \pm 0.07$ & $0 . \mathrm{II} \pm 0.06$ & $0.0 \pm 0.0$ & 6 & $0.03 \pm 0.01$ & E-M \\
\hline Cerastium arvense & $0.09 \pm 0.01$ & $0.06 \pm 0.02$ & $0.02 \pm 0.01$ & $0.03 \pm 0.02$ & II & $0.19 \pm 0.06$ & $\mathrm{E}$ \\
\hline $\begin{array}{l}\text { Symphyotrichum } \\
\text { ericoides }\end{array}$ & $0.08 \pm 0.0$ & $0.0 \mathrm{I} \pm 0.00$ & $0.0 \pm 0.0$ & $0.0 \mathrm{I} \pm 0.0 \mathrm{I}$ & 6 & $0.7 \mathrm{I} \pm 0.3 \mathrm{I}$ & $\mathrm{L}$ \\
\hline Liatris ligulistylis & $0.07 \pm 0.04$ & $0.24 \pm 0.12$ & $0.18 \pm 0.09$ & $0.02 \pm 0.02$ & 8 & $0.03 \pm 0.0 \mathrm{I}$ & $\mathrm{L}$ \\
\hline Erigeron strigosus & $0.07 \pm 0.0$ & $0.15 \pm 0.09$ & $0.0 \pm 0.0$ & $0.15 \pm 0.08$ & 4 & $0.04 \pm 0.01$ & M \\
\hline Vicia americana & $0.07 \pm 0.0$ & $0 . \mathrm{II} \pm 0.04$ & $0.10 \pm 0.04$ & $0.02 \pm 0.02$ & 6 & $0.10 \pm 0.03$ & E-M \\
\hline Cirsium drummondii & $0.06 \pm 0.05$ & $\mathrm{I.I8} \pm 0.4 \mathrm{I}$ & $\mathrm{I} .17 \pm 0.4 \mathrm{I}$ & $0.0 \pm 0.0$ & I0 & $0.02 \pm 0.01$ & E-M \\
\hline Agastache foeniculum & $0.06 \pm 0.03$ & $0.46 \pm 0.16$ & $0.45 \pm 0.16$ & $0.0 \pm 0.0$ & I0 & $0.08 \pm 0.02$ & M-L \\
\hline Monarda fistulosa & $0.06 \pm 0.02$ & $0.37 \pm 0.14$ & $0.32 \pm 0.12$ & $0.0 \pm 0.0$ & $\mathrm{I} 2$ & $0.16 \pm 0.05$ & M-L \\
\hline Liatris punctata & $0.05 \pm 0.0$ & $0.22 \pm 0.08$ & $0 . \mathrm{II} \pm 0.06$ & $0.04 \pm 0.04$ & 4 & $0.04 \pm 0.02$ & $\mathrm{~L}$ \\
\hline Helianthus pauciflorus & $0.05 \pm 0.0$ & $0.19 \pm 0.08$ & $0.10 \pm 0.07$ & $0.16 \pm 0.06$ & 4 & $0.04 \pm 0.02$ & $\mathrm{~L}$ \\
\hline Hedysarum boreale & $0.05 \pm 0.0 \mathrm{I}$ & $0.18 \pm 0.05$ & $0.18 \pm 0.05$ & $0.0 \pm 0.0$ & 5 & $0.23 \pm 0.07$ & M \\
\hline Astragalus crassicarpus & $0.05 \pm 0.04$ & $0.15 \pm 0.04$ & $0.04 \pm 0.03$ & $0.0 \pm 0.0$ & 7 & $0.17 \pm 0.06$ & E-M \\
\hline Geum triflorum & $0.05 \pm 0.02$ & $0.05 \pm 0.02$ & $0.05 \pm 0.02$ & $0.0 \pm 0.0$ & 7 & $0.59 \pm 0.15$ & E \\
\hline Zizia aptera & $0.04 \pm 0.03$ & $0.19 \pm 0.06$ & $0.06 \pm 0.02$ & $0 . \mathrm{II} \pm 0.04$ & $\mathrm{I} 3$ & $0.12 \pm 0.05$ & E \\
\hline Agoseris glauca & $0.04 \pm 0.01$ & $0.22 \pm 0.08$ & $0.13 \pm 0.07$ & $0.06 \pm 0.05$ & 5 & $0.02 \pm 0.01$ & M-L \\
\hline Allium stellatum & $0.04 \pm 0.02$ & $0.04 \pm 0.03$ & $0.04 \pm 0.02$ & $0.0 \mathrm{I} \pm 0.0 \mathrm{I}$ & 4 & $0.04 \pm 0.02$ & $\mathrm{~L}$ \\
\hline $\begin{array}{l}\text { Lithospermum } \\
\text { canescens }\end{array}$ & $0.04 \pm 0.02$ & $0.02 \pm 0.01$ & $0.01 \pm 0.0$ & $0.0 \pm 0.0$ & 10 & $0.68 \pm 0.22$ & E \\
\hline Dalea purpurea & $0.03 \pm 0.01$ & $0.79 \pm 0.35$ & $0.78 \pm 0.35$ & $0.01 \pm 0.0$ & 8 & $0.13 \pm 0.05$ & $\mathrm{~L}$ \\
\hline
\end{tabular}


Table I continued.

\begin{tabular}{|c|c|c|c|c|c|c|c|}
\hline Scientific name & $\begin{array}{l}\mathrm{G}(\text { mean } \\
\pm \mathrm{SE})^{\mathrm{I}}\end{array}$ & $\begin{array}{l}\text { Insect }^{2} \\
\text { visitation rate } \\
\text { (mean visits } \\
\text { infl. }^{-1} \text { day }^{-} \\
{ }^{I} \pm \text { SE) }\end{array}$ & $\begin{array}{l}\mathrm{Bee}^{3} \text { visitation } \\
\text { rate (mean } \\
\text { visits infl.- } \\
{ }^{\mathrm{I}} \mathrm{day}^{-\mathrm{I}} \pm \mathrm{SE} \text { ) }\end{array}$ & $\begin{array}{l}\text { Diptera } \\
\text { visitation rate } \\
\text { (mean visits } \\
\text { infl. }{ }^{-1} \text { day } \\
{ }^{\mathrm{I}} \pm \mathrm{SE} \text { ) }\end{array}$ & $\begin{array}{l}\mathrm{S} \text { (total \# } \\
\text { of insect } \\
\text { visitor } \\
\operatorname{taxa})\end{array}$ & $\begin{array}{l}\text { Infl. density } \\
\text { (mean } \\
\left.\# / \mathrm{m}^{2} \pm \mathrm{SE}\right)\end{array}$ & $\begin{array}{l}\text { Flowering } \\
\text { period }^{4}\end{array}$ \\
\hline Tragopogon dubius & $0.03 \pm 0.0$ & $0.13 \pm 0.12$ & $0.08 \pm 0.08$ & $0.04 \pm 0.04$ & 2 & $0.0 \mathrm{I} \pm 0.0 \mathrm{I}$ & $\mathrm{E}$ \\
\hline Gaillardia aristata & $0.03 \pm 0.02$ & $0.12 \pm 0.06$ & $0.08 \pm 0.05$ & $0.03 \pm 0.03$ & 4 & $0.02 \pm 0.0 \mathrm{I}$ & M-L \\
\hline Oxytropis campestris & $0.03 \pm 0.0$ & $0.1 \mathrm{I} \pm 0.02$ & $0.09 \pm 0.02$ & $0.0 \pm 0.0$ & 4 & $0.19 \pm 0.06$ & M \\
\hline Galium boreale & $0.03 \pm 0.02$ & $0.04 \pm 0.03$ & $0.01 \pm 0.0$ & $0.0 \mathrm{I} \pm 0.0 \mathrm{I}$ & 5 & $0.27 \pm 0.09$ & M \\
\hline Rosa acicularis & $0.02 \pm 0.01$ & $0.55 \pm 0.26$ & $0.02 \pm 0.01$ & $0.53 \pm 0.26$ & 6 & $0.03 \pm 0.01$ & E-M \\
\hline Astragalus agrestis & $0.02 \pm 0.0 \mathrm{I}$ & $0.19 \pm 0.05$ & $0.16 \pm 0.02$ & $0.0 \pm 0.0$ & 3 & $0.04 \pm 0.0 \mathrm{I}$ & E \\
\hline Penstemon gracilis & $0.02 \pm 0.0 \mathrm{I}$ & $0 . \mathrm{I} 4 \pm 0 . \mathrm{II}$ & $0.14 \pm 0.10$ & $0.0 \pm 0.0$ & 3 & $0.02 \pm 0.0 \mathrm{I}$ & M \\
\hline Heuchera richardsonii & $0.02 \pm 0.01$ & $0 . \mathrm{II} \pm 0.04$ & $0 . \mathrm{II} \pm 0.04$ & $0.0 \pm 0.0$ & 4 & $0.02 \pm 0.01$ & E-M \\
\hline $\begin{array}{l}\text { Pediomelum } \\
\text { esculentum }\end{array}$ & $0.02 \pm 0.01$ & $0.1 \mathrm{I} \pm 0.05$ & $0.10 \pm 0.05$ & $0.0 \pm 0.0$ & 3 & $0.04 \pm 0.01$ & E-M \\
\hline Polygala senega & $0.02 \pm 0.02$ & $0.0 \mathrm{I} \pm 0.0 \mathrm{I}$ & $0.0 \pm 0.0$ & $0.0 \pm 0.0$ & 4 & $0.2 \mathrm{I} \pm 0.08$ & E \\
\hline Fragaria virginiana & $0.0 \mathrm{I} \pm 0.0 \mathrm{I}$ & $0.0 \mathrm{I} \pm 0.0 \mathrm{I}$ & $0.01 \pm 0.0$ & $0.0 \pm 0.0$ & 2 & $0.06 \pm 0.02$ & E \\
\hline
\end{tabular}

${ }^{\mathrm{I}} \mathrm{G}=$ generalization score. A G score (see Methods section for the formula) was calculated for each of the three sites using pooled data over two years (Appendix I) and averaged if the plant occurred at more than one site.

${ }^{2}$ Includes the visits by all insect taxa pooled over two years and averaged from all three sites.

${ }^{3}$ Includes only visits by bees (Hymenoptera) in the Andrenidae, Apidae, Colletidae, Halictidae and Megachilidae pooled over two years and averaged from all three sites.

${ }^{4} \mathrm{E}=$ Early (June), M=Mid (July), L= Late (August-September). Determined using pooled data over two years from all three sites.

drummondii, Dalea purpurea, Agastache foeniculum and Monarda fistulosa. This is because these plants were visited frequently by two of the most frequently observed insect taxa - Bombus ternarius and B. sandersoni (Tab. 2) - which greatly decreased the evenness and consequently the $\mathrm{G}$ score. Rosa acicularis was among the most frequently visited plants but its visitors were mainly root maggot flies (Drymeia sp.) not bumblebees (Bombus spp.).

The average density of each plant varied from a high of 0.7 inflorescences $/ \mathrm{m}^{2}$ for Symphyotrichum ericoides to $<$ 0.I inflorescences $/ \mathrm{m}^{2}$ for Tragopogon dubius. Differences in inflorescence density may have influenced the G scores as these two variables were strongly positively correlated $(y=$ $\left.0.3393 x+2.202, \mathrm{R}^{2}=0.2186, P<0.001\right)$. This may be in part because species with low densities were observed for less time than more abundant plants, potentially decreasing the number of insect visitor taxa observed and influencing the $G$ score. However, inflorescence density was not correlated with the insect visitation rate per inflorescence $(y=$ $\left.0.1839 \mathrm{x}+2.6452, \mathrm{R}^{2}=0.0287, P=0.25\right)$, bee visitation rate per inflorescence $\left(y=-0.0224 x+2.4753, \mathrm{R}^{2}=\right.$ $0.0004, P=0.25)$ or fly visitation rate per inflorescence (y $\left.=-0.0017 \mathrm{x}+2.3504, \mathrm{R}^{2}=6 \mathrm{E}^{-06}, P=0.99\right)$ suggesting that factors other than abundance are being used by some insects to select plants. Indeed some species with low densities had some of the highest visitation rates per inflorescence (e.g. Prunus virginiana and Solidago canadensis).

The insect taxa observed in this study belonged to five orders: 7 beetle species (Coleoptera), 39 fly species
(Diptera), 3 bug species (Hemiptera), 39 bee, ant and wasp species (Hymenoptera) and 22 butterfly and moth species (Lepidoptera) (Tab, 2). The Hymenoptera consisted of mostly bees (29 species), seven species of wasps, two species of ants and one sawfly. On average, Bombus species together made $54.7 \%$ of the visits at each site, with Bombus ternarius alone responsible for over $32.0 \%$. Bombus species also visited the greatest number of plant species: $12.4 \%$ over the whole course of the study on average compared to $3.7 \%$ for all other taxa. The root maggot fly Drymeia sp. was the most frequently observed fly taxon making on average $3.8 \%$ of all insect visits, mainly to Rosa acicularis. Of the fly species observed, the tachinid Peleteria sp. visited the highest number of plant species (I2). Most insect taxa (56.0\%) were observed in only one time period (e.g. early, mid or late summer) but $28.0 \%$ were observed in two periods and I5.0\% in all three. The taxa most frequently observed were also the ones observed over the longest period of time.

The species accumulation curve for all insect visitor taxa indicates that most $(90 \%)$ would have at least one appropriate forage plant once 16 of the most generalized plants were present (Fig. I). Fly taxa reached the $90 \%$ point after nine of the most generalized plant species were added, and bees after $\mathrm{I} 3$ species. Figure 2 shows the flowering range of all the plants observed being visited by insects during the survey period. Of the 16 most generalized plant species (see Table I) seven began flowering in June, six in July and three in August. 
TABLE 2. The time period when 20 insect visitor taxa with the highest percentage of visits and number of plant species visited (S) in three fescue prairie sites in southern Manitoba were observed.

\begin{tabular}{|c|c|c|c|c|c|c|}
\hline Order & Family & Common Name & Scientific Name & $\begin{array}{l}\text { Time } \\
\text { period }^{\mathrm{I}}\end{array}$ & $\begin{array}{l}\text { Visits (mean } \\
\% / \text { site } \pm S E)^{2}\end{array}$ & $\begin{array}{l}\mathrm{S} \text { (total \# of } \\
\text { plant species } \\
\text { visited) }\end{array}$ \\
\hline Hymenoptera & Apidae & $\begin{array}{l}\text { Tri-colored } \\
\text { bumblebee }\end{array}$ & Bombus ternarius & E-M-L & $32.4 \pm 5.3$ & 18 \\
\hline Hymenoptera & Apidae & $\begin{array}{l}\text { Sanderson } \\
\text { bumblebee }\end{array}$ & Bombus sandersoni & E-M-L & $9.5 \pm \mathrm{I} .7$ & $2 \mathrm{I}$ \\
\hline Hymenoptera & Apidae & Nevada bumblebee & Bombus nevadensis & E-M-L & $4.8 \pm \mathrm{I} .5$ & 18 \\
\hline Diptera & Muscidae & Root maggot fly & Drymeia sp. & E-M & $3.8 \pm 1.9$ & 3 \\
\hline Diptera & Tachinidae & Tachinid fly & Tachina sp. & M-L & $3.2 \pm 0.2$ & 7 \\
\hline Hymenoptera & Halictidae & Sweat bee & $\begin{array}{l}\text { Augochlorella } \\
\text { aurata }\end{array}$ & E-M-L & $2.5 \pm 0.99$ & $\mathrm{I} 4$ \\
\hline Hymenoptera & Apidae & $\begin{array}{l}\text { Northern amber } \\
\text { bumblebee }\end{array}$ & Bombus borealis & E-M-L & $2.5 \pm 0.86$ & I3 \\
\hline Diptera & Tachinidae & Tachinid fly & Chaetogaedia sp. & $\mathrm{L}$ & $2.5 \pm 0.95$ & 7 \\
\hline Hymenoptera & Apidae & $\begin{array}{l}\text { Yellow-banded } \\
\text { bumblebee }\end{array}$ & Bombus terricola & E-M-L & $2.2 \pm 0.49$ & 7 \\
\hline Diptera & Bombyliidae & Bee fly & $\begin{array}{l}\text { Poecilanthrax } \\
\text { alycon }\end{array}$ & $\mathrm{L}$ & $1.9 \pm 0.60$ & 8 \\
\hline Hymenoptera & Apidae & $\begin{array}{l}\text { Confusing } \\
\text { bumblebee }\end{array}$ & Bombus perplexus & $\mathrm{L}$ & $1.8 \pm 0.90$ & 6 \\
\hline Diptera & Tachinidae & Tachinid fly & Peleteria sp. & $\mathrm{L}$ & $1.6 \pm 0.20$ & $\mathrm{I} 2$ \\
\hline Hymenoptera & Megachilidae & $\begin{array}{l}\text { Unarmed leaf-cutter } \\
\text { bee }\end{array}$ & Megachile inermis & E-M-L & $1.6 \pm 0.5 \mathrm{I}$ & I0 \\
\hline Hymenoptera & Apidae & $\begin{array}{l}\text { Red-belted } \\
\text { bumblebee }\end{array}$ & Bombus rufocinctus & $\mathrm{L}$ & $1.5 \pm 0.73$ & 4 \\
\hline Diptera & Syrphidae & Hover fly & $\begin{array}{l}\text { Toxomerus } \\
\text { geminatus }\end{array}$ & E-M-L & $1.3 \pm 0.08$ & II \\
\hline Hymenoptera & Halictidae & Sweat bee & $\begin{array}{l}\text { Lasioglossum } \\
\text { succinipenne }\end{array}$ & E-M-L & $1.3 \pm 0.58$ & I0 \\
\hline Diptera & Bombyliidae & Bee fly & Villa nigra & $\mathrm{L}$ & I. $3 \pm 0.43$ & 3 \\
\hline Hymenoptera & Megachilidae & $\begin{array}{l}\text { Small-handed leaf- } \\
\text { cutter bee }\end{array}$ & Megachile gemula & E-M-L & $1.2 \pm 0.33$ & I0 \\
\hline Lepidoptera & Lycaenidae & Silvery blue & $\begin{array}{l}\text { Glaucopsyche } \\
\text { lygdamus }\end{array}$ & E-M & 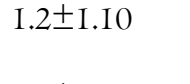 & 8 \\
\hline Hymenoptera & Andrenidae & Miserable andrena & Andrena miserabilis & E-M-L & $1.2 \pm 0.39$ & 6 \\
\hline Other Diptera & $\mathrm{n} / \mathrm{a}$ & Flies & 32 spp. & E-M-L & II.6 & 27 \\
\hline $\begin{array}{l}\text { Other } \\
\text { Hymenoptera } \\
\text { (bees) }\end{array}$ & $\mathrm{n} / \mathrm{a}$ & Bees & I7 spp. & E-M-L & 8.0 & 29 \\
\hline $\begin{array}{l}\text { Other } \\
\text { Lepidoptera }\end{array}$ & $\mathrm{n} / \mathrm{a}$ & Butterflies/moths & 2I spp. & E-M-L & 7.6 & 25 \\
\hline $\begin{array}{l}\text { Other } \\
\text { Hymenoptera } \\
\text { (ants \& wasps) }\end{array}$ & $\mathrm{n} / \mathrm{a}$ & Ants/wasps & I0 spp. & E-M-L & 2.6 & $\mathrm{I} 2$ \\
\hline $\begin{array}{l}\text { Coleoptera/ } \\
\text { Hemiptera }\end{array}$ & $\mathrm{n} / \mathrm{a}$ & Beetles/bugs & I0 spp. & E-M-L & 2.6 & 9 \\
\hline
\end{tabular}

${ }^{\mathrm{I}} \mathrm{E}=$ Early (June), M=Mid (July), L= Late (August-September). Determined using pooled data over two years from all three sites.

${ }^{2}$ The $\%$ of visits was calculated for each taxa at each of three sites using pooled data over two years and averaged if the insect was seen at more than one site.

\section{DISCUSSION}

The results of this study and many others (Forup et al. 2008; Devoto et al. 2012; Montoya et al. 20I2; Russo et al. 2013) suggest that just a small number of the most generalized entomophilous plant species supply most of the insect pollinator taxa in a community with appropriate forage. This likely has to do with the functional redundancy of some plant species for the pollinator community (Goldstein \& Zych 2016). For example, many of the legumes (e.g. Astragalus spp., Vicia americana, Hedysarum 


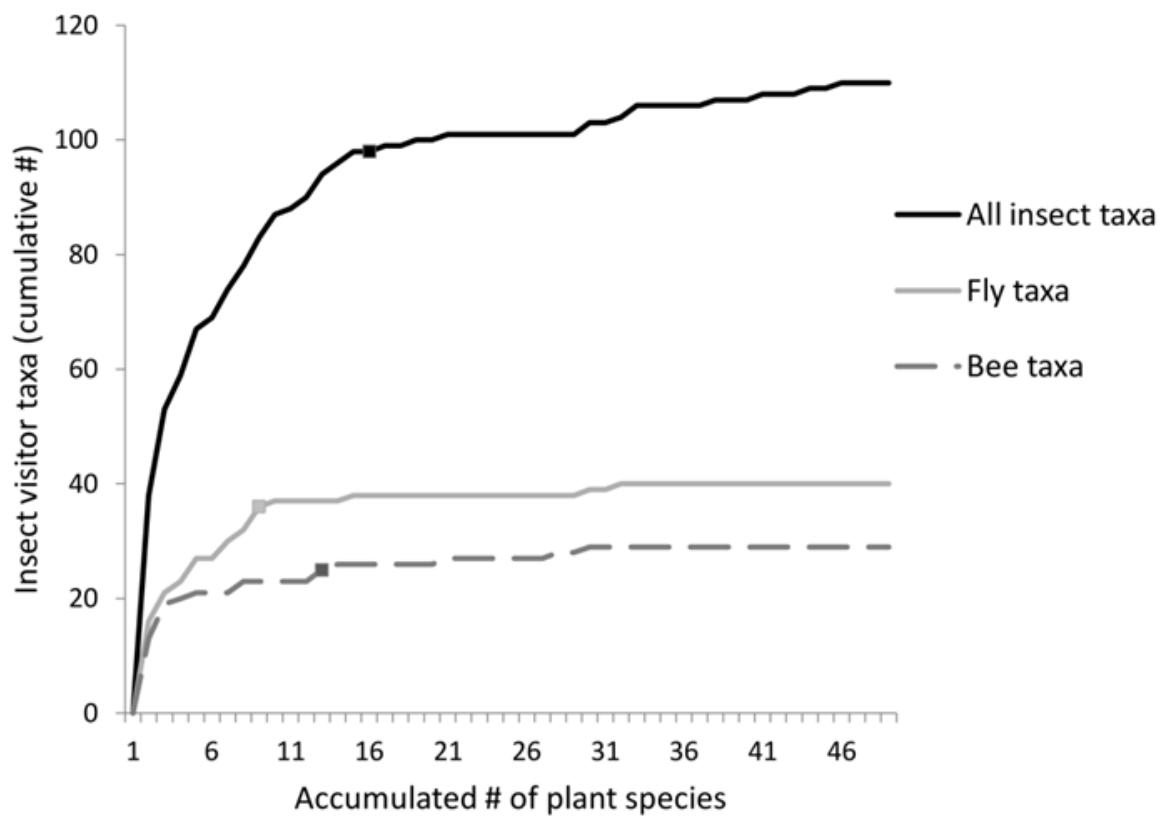

Figure I. Species accumulation curves for all insect visitor taxa recorded (IIO), also broken down for the taxa of flies (39) and bees (29) as the most to the least generalized plants are added. Squares represent the points at which the plant species present were visited by $90 \%$ of all insect taxa in that group.

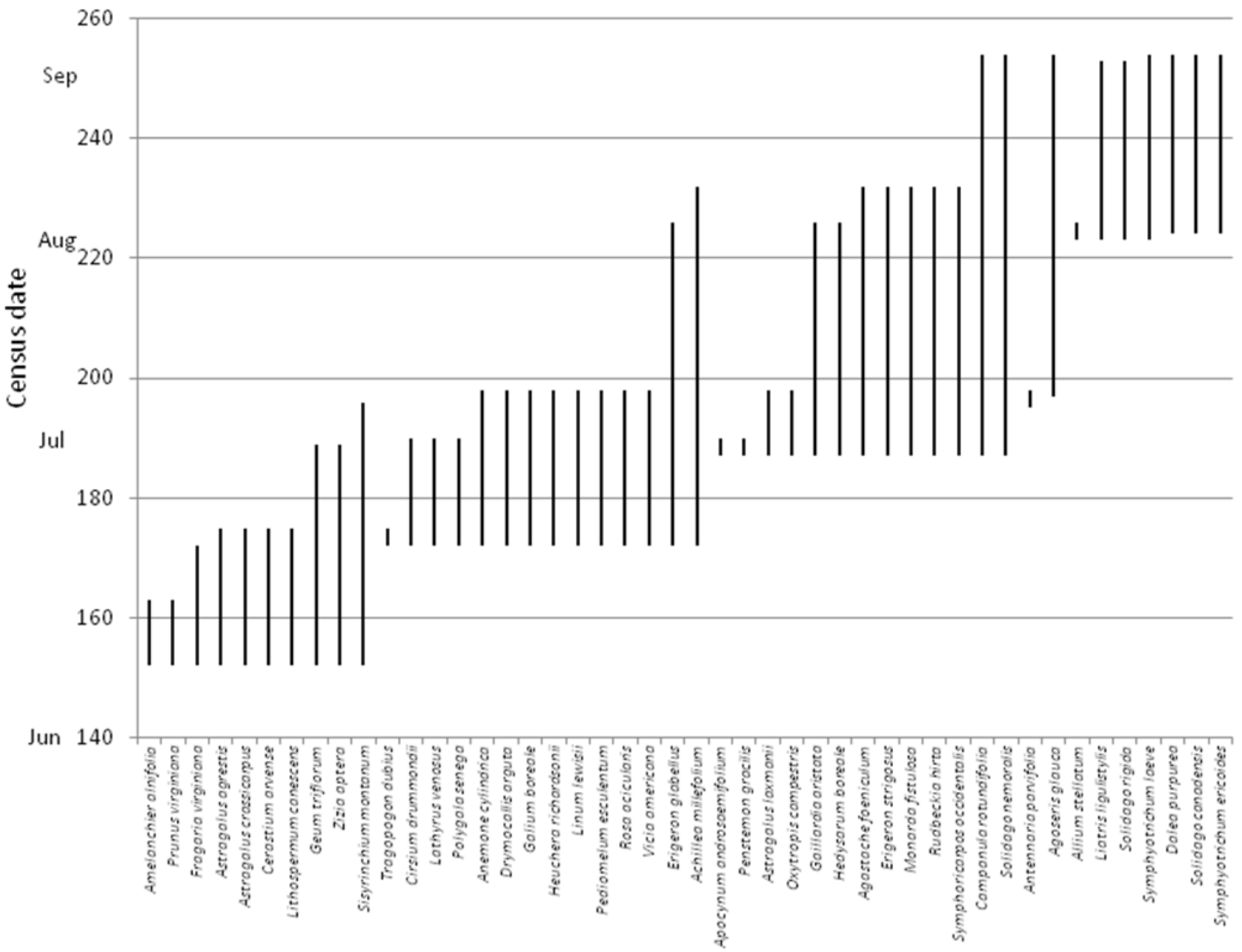

FIGURE 2. Flowering phenology of 48 plant species in south western Manitoba observed over 102 calendar days ordered by earliest to latest flowering period. The line indicates the flowering duration in the research plots using merged 2014 and 2015 survey data. 
boreale and Dalea purpurea) were visited by the exact same suite of insect taxa. However, the aforementioned legumes flower at different times so at least three species would be needed to provide the insect community with consistent leguminous forage over the year. This is important to remember as restoration ecologists are often under pressure to keep costs down. Wilkerson et al. (20I4) found that although using a seed mix with nine species had the highest germination, cover and floral resources, it was not as cost effective as a mix with only five species due to the higher price. However, the actual diversity of pollinators was not assessed in the Wilkerson study. Although adding fewer species may be more cost effective, doing so may result in inadequate floral resources: in our study less than $1 \%$ of all early summer insect visits would have occurred if only the top five plant species (in terms of their $G$ scores) were present. A lack of early blooming flowers inhibits the development of healthy bumble bee colonies, which start out in spring with a single queen (Goulson 2003; Goulson et al. 2015; Isaacs et al. 2009). By determining G scores and preparing species accumulation curves with our data, we were able to identify the minimum number of species that would be needed to provide forage for most insect taxa over the entire growing season.

In addition to species with high generalization scores, it may be beneficial to add more specialized plant species to a seed mix if providing consistent forage for bees is desirable. Several studies have shown that Bombus spp. preferred plants with relatively deep nectar tubes (Stang et al. 2006; Forup et al. 2008; Elle et al. 2012), and researchers have found that adding such plants (particularly legumes) to restored areas results in increased richness and abundance of this genus (M'Gonigle et al. 20I5; Carvell et al. 20II). Although four of the top ten plant species most frequently visited by bees were among the 16 most generalized plants, six species were not. These six plants had purple flowers and short to long nectar tubes that could only be accessed by relatively longertongued insects: Cirsium drummondii, Dalea purpurea, Agastache foeniculum, Monarda fistulosa, Hedysarum boreale and Liatris ligulistylis. The differences in the species with the highest $G$ scores and insect visitation rates per inflorescence are due to bee preferences for the aforementioned flowers. In general, plants with the highest visitation rates were visited mainly by bees but one species was frequently visited by flies: Rosa acicularis. This rose had a low $\mathrm{G}$ score but a high visitation rate mainly due a species of Drymeia that swarmed the flowers once they bloomed, quickly removing all pollen. Therefore, specialized plant species should not be discounted for inclusion in wildflower plantings, if they are frequently visited. The visitation rate per inflorescence was thus a valuable metric to identify popular species.

Unfortunately, two of the plant species with the highest generalization scores appear to be currently unavailable from Canadian native seed supply companies (NPSS 2013): Astragalus laxmannii and Cerastium arvense. Seeds of these species are likely unavailable because they are difficult to harvest or germinate (Baskin \& Baskin 1998). Further, seeds from the plant with the highest visitation rate per inflorescence (Cirsium drummondii) appear to be unavailable as the plant is uncommon and, due to its prickly leaves, not generally considered a desirable plant (although its popularity with bees may encourage restoration specialists to reconsider it). In the event these plants cannot be acquired, potential substitutes that flower in the same season with slightly lower $\mathrm{G}$ scores or visitation rates, and are visited by a similar subset of pollinators, could be selected instead. For example, Geum triflorum or Astragalus crassicarpus could be substituted for Cerastium arvense as they all flower at the same time. Possible substitutes for the mid-summer species -Astragalus laxmannii and Cirsium drummondii- are two leguminous species: Vicia americana and/or Hedysarum boreale. Spreading native hay is another possible strategy to introduce propagules for a restoration (Donath et al. 2007), but this may be difficult due the high number of invasive plants present in most fescue prairies.

There are several limitations of this study that need to be considered. Although moths are important pollinators in northern ecosystems (MacGregor et al. 20I5), nocturnal insect activity was not monitored and, as a result, the importance of some plant species was likely underestimated. In addition, the 48 plant species were not observed for an equal length of time due to their natural variability in abundance. The possibility for modification to the $G$ score to adjust for differences plant abundance was not addressed in the original reference (Medan et al. 2006), so additional observations are needed for the rarer species. An assumption was made that if these plants are grown as part of a prairie restoration, the insect taxa that were observed under natural conditions would eventually begin to inhabit the site. However, some studies comparing plant-pollinator communities in restored habitats have found that although they eventually function in a similar way, species composition between sites was somewhat different, possibly due to habitat differences (Forup and Memmott 2005; Forup et al. 2008; Menz et al. 20II; Tarrant et al. 2012). Further, there are strong temporal variations in insect pollinator composition from year to year (Dupont et al. 2009; MacLeod et al. 2016; CaraDonna et al. 2017). Thus, a restored prairie may not have the exact same composition as a native reference community. However, Forup et al. (2008) argues that restoration success should be based less on pollinator composition and more on functional similarity. This is because increased species richness may not be strongly correlated with functional diversity (Mayfield et al. 2010; Cadotte et al. 201I). Assessing the functional diversity of an ecosystem is increasingly being used to help set restoration goals (Thorpe \& Stanley 20I I; Giannini et al. 2016) and assess community health (Cadotte et al. 20I I).

Considering all our data and the aforementioned studies, we propose one possible species list for fescue prairie restoration (Tab. 3). It includes 16 of the most generalized plants, plus four that are more specialized but frequently visited: Agastache foeniculum, Dalea purpurea, Monarda fistulosa and Rosa acicularis. All of the species in Tab. 3 were also among the top ten most generalized plants at the individual sites except one (Liatris ligulistylis). The plants on this list are in eight families: Asteraceae ( 7 species), Rosaceae (4), Fabaceae (3), Lamiaceae (2), and one species each in the Apocynaceae, Campanulaceae, Caprifoliaceae and Linaceae. 
TABLE 3. Suggested minimum fescue prairie seed mix, and data regarding the expected insect community that would be supported by it.

\begin{tabular}{|c|c|c|c|c|}
\hline $\begin{array}{l}\text { Flowering } \\
\text { period }\end{array}$ & Species & $\begin{array}{l}\text { Insect taxa } \\
(\text { cumulative \#) })^{\mathrm{I}}\end{array}$ & $\begin{array}{l}\text { Insect visits } \\
(\text { cumulative \%) }\end{array}$ & Most attracted insect taxa ${ }^{\mathrm{I}}$ \\
\hline \multirow[t]{5}{*}{ Early } & Geum triflorum ${ }^{2}$ & 7 & 2.0 & Eusocial \& solitary bees \\
\hline & Prunus virginiana & $\mathrm{I} 3$ & 3.0 & Beetles \& bees \\
\hline & Rosa acicularis & 18 & 4.2 & Flies \& solitary bees \\
\hline & Lathyrus venosus & $2 \mathrm{I}$ & 4.5 & Butterflies \& eusocial bees \\
\hline & Linum lewisii & 30 & 5.5 & Flies \& butterflies \\
\hline \multirow[t]{3}{*}{ Early-mid } & Apocynum androsaemifolium & 35 & 5.9 & Solitary bees \& flies \\
\hline & Drymocallis arguta & $4 \mathrm{I}$ & 7.6 & Solitary bees \& beetles \\
\hline & Vicia americana ${ }^{3}$ & 42 & 9.1 & Butterflies \& eusocial bees \\
\hline \multirow[t]{6}{*}{ Mid } & Rudbeckia hirta & 53 & 10.9 & Flies \& butterflies \\
\hline & Achillea millefolium & $6 \mathrm{I}$ & $\mathrm{I} 2.4$ & Beetles \& flies \\
\hline & Campanula rotundifolia & 67 & $\mathrm{I} 4.5$ & Solitary \& eusocial bees \\
\hline & Erigeron glabellus & 68 & 16.5 & Flies \& butterflies \\
\hline & Monarda fistulosa & 69 & 20.1 & Eusocial bees \& butterflies \\
\hline & Symphoricarpos occidentalis & 74 & 25.8 & Flies $\&$ eusocial bees \\
\hline \multirow[t]{6}{*}{ Late } & Solidago rigida & 86 & 43.3 & Flies $\&$ beetles \\
\hline & Agastache foeniculum & 86 & 45.6 & Eusocial \& solitary bees \\
\hline & Solidago canadensis & 90 & 47.2 & Beetles \& solitary bees \\
\hline & Solidago nemoralis & 96 & 55.5 & Beetles \& flies \\
\hline & Symphyotrichum laeve & 98 & 69.7 & Eusocial bees \& flies \\
\hline & Dalea purpurea & 98 & 77.6 & Eusocial bees \& butterflies \\
\hline
\end{tabular}

IBased on 20I4-20I5 insect visitation observations in fescue prairie.

${ }^{2}$ This species is a suggested substitute if seeds of Cerastium arvense are unavailable from commercial Canadian seed suppliers ${ }^{3}$ This species is a suggested substitute if seeds of Astragalus laxmannii are unavailable from commercial Canadian seed suppliers

Three of the species were shrubs (i.e. Prunus virginiana, Symphoricarpos occidentalis and Rosa acicularis) and the remainder are herbaceous. Almost $90 \%$ of all insect taxa observed visited at least one of the 20 plants on this list. All of the major insect flower visitor groups (i.e. eusocial \& solitary bees, beetles, butterflies and flies) would have at least one plant they favoured in each flowering period (i.e. early, early-mid, mid and late summer). Many of the species we recommended were previously noted as being important pollen and nectar sources for pollinators in North America including: Agastache foeniculum, Campanula rotundifolia, Dalea purpurea, Monarda fistulosa, Prunus virginiana, Solidago spp., Symphoricarpos occidentalis and Symphyotrichum spp. (Isaacs et al. 2009; Mader et al. 20I I; Evans 2013). Substitutions could, of course, be made to accommodate different environmental conditions but care should be taken to select species that flower at the same time and support a similar insect community. For example, Liatris ligulistylis could be added instead of Dalea purpurea where the soils are relatively moist as the latter species appears to be less tolerant of such conditions (Anderson \& Schelfhout 1980). Differences in seed availability may also affect the precise mix. This seed mix should be considered the minimum number of forb/shrub species for any fescue prairie restoration. The addition of other plant species may be important to meet other restoration goals, such as increasing the total plant richness or providing appropriate floral resources for rare pollinators such as oligolectic bees (Sheffield et al. 2014) or butterflies such as Danaus plexippus (Landis 2014). Additional research on pollination in fescue prairie is needed to: (I) identify pollinators of plant species we missed, (2) determine the plant species required by rarer pollinators, (3) determine if there is regional variability in the pollinator community, and (4) determine what role landscape variability may have on pollinator nesting.

\section{ACKNOWLEDGEMENTS}

The authors gratefully acknowledge the financial support of the Nature Conservancy of Canada and The Manitoba Museum Foundation Inc. Thanks to the Government of Manitoba for permitting research on their lands. We are grateful for Manitoba Museum staff and volunteer assistance with specimen processing. Special thanks to Sarah Semmler for preparation and identification of insect specimens. We are also grateful to the reviewers of this manuscript for their thoughtful comments, which greatly improved our paper.

\section{APPENDICES}

Additional supporting information may be found in the online version of this article:

APPENDIX I. Generalization scores (G) for vascular plant species in three fescue prairie sites in southern Manitoba. 
APPENDIX II. Two-year pooled plant-insect visitor matrix in three fescue prairie sites, Manitoba.

\section{REFERENCES}

Analyze-it Software, Ltd. (2009) http://www.analyse-it.com/.

Anderson RC, Schelfhout S (1980) Phenological patterns among tallgrass prairie plants and their implication for pollinator competition. The American Midland Naturalist I04:253-263.

Bascompte J, Jordano P (2007) Plant-animal mutualistic networks: the architecture of biodiversity. Annual Review of Ecology, Evolution and Systematics 38:567-593.

Baskin CC, Baskin JM (1998) Seeds: ecology, biogeography, and, evolution of dormancy and germination. Elsevier

Cadotte MW, Carscadden K, Mirotchnick N (201I). Beyond species: functional diversity and the maintenance of ecological processes and services. Journal of Applied Ecology 48:10791087.

CaraDonna PJ, Petry WK, Brennan RM, Cunningham JL, Bronstein JL, Waser NM, Sanders NJ (20I7) Interaction rewiring and the rapid turnover of plant-pollinator networks. Ecology Letters 20:385-94

Carvell C, Osborne JL, Bourke AFG, Freeman SN, Pywell RF, Heard MS (20II) Bumble bee species' responses to a targeted conservation measure depend on landscape context and habitat quality. Ecological Applications 2I:1760-177I.

Chuine I (2010) Why does phenology drive species distribution? Philosophical Transactions B Royal Society of London 365:3I49-3I60.

Coupland RT (196I) A reconsideration of grassland classification in the northern great plains of North America. Journal of Ecology 49:135-167.

Coupland RT, Brayshaw TC (1953) The fescue grassland in Saskatchewan. Ecology 34:386-405.

Devoto M, Bailey S, Craze P, Memmott J (2012) Understanding and planning ecological restoration of plant-pollinator networks. Ecology Letters 15:319-328.

Donath TW, Bissels S, Hölzel N, Otte A (2007) Large scale application of diaspore transfer with plant material in restoration practice-Impact of seed and microsite limitation. Biological Conservation I38:224-234.

Dupont YL, Padrón B, Olesen JM, Petanidou T (2009) Spatio-temporal variation in the structure of pollination networks. Oikos I 18:126I-9.]

Ebeling A, Klein AM, Schumacher J, Weisser WW, Tscharntke T (2008) How does plant richness affect pollinator richness and temporal stability of flower visits? Oikos I I7:I808-I5.

Elle E, Elwell SL, Gielens GA (2012) The use of pollination networks in conservation. Botany 90:525-534.

Evans MM (2013) Influences of grazing and landscape on bee pollinators and their floral resources in rough fescue grassland. M.Sc. Dissertation, University of Calgary, Calgary, Alberta.

Forup ML, Memmott J (2005) The restoration of plant-pollinator interactions in hay meadows. Restoration Ecology 13:265-274.

Forup ML, Henson KS, Craze PG, Memmott J (2008) The restoration of ecological interactions: plant-pollinator networks on ancient and restored heathlands. Journal of Applied Ecology 45:742-752.

Giannini TC, Giulietti AM, Harley RM, Viana PL, Jaffe R, Alves R, Pinto CE, Mota NF, Caldeira CF, Imperatriz-Fonseca VL, Furtini AE (2016) Selecting plant species for practical restoration of degraded lands using a multiple-trait approach. Austral Ecology.

Gibson RH, Knott B, Eberlein T, Memmott J (201I) Sampling method influences the structure of plant-pollinator networks. Oikos I20:822-83I.

Goldstein J, Zych M (2016). What if we lose a hub? Experimental testing of pollination network resilience to removal of keystone floral resources. Arthropod-Plant Interactions I0:263-27I.

Goulson D (2003) Bumblebees: behaviour and ecology. Oxford Univ. Press.

Goulson D, Nicholls E, Botías C, Rotheray EL (2015) Bee declines driven by combined stress from parasites, pesticides, and lack of flowers. Science 347:1255957.

Harmon-Threatt AN, Hendrix SD (2015) Prairie restorations and bees: the potential ability of seed mixes to foster native bee communities. Basic and Applied Ecology 6:64-72.

Isaacs R, Tuell J, Fiedler A, Gardiner M, Landis D (2009) Maximizing arthropod-mediated ecosystem services in agricultural landscapes: the role of native plants. Frontiers in Ecology and the Environment 7:196-203.

Jordano P, Bascompte J, Olesen JM (2003) Invariant properties in coevolutionary networks of plant-animal interactions. Ecology Letters 6:69-8I.

Kevan PG, Baker HG (1983) Insects as flower visitors and pollinators. Annual Review of Entomology 28:407-453.

Kremen C, M'Gonigle LK (2015). Small-scale restoration in intensive agricultural landscapes supports more specialized and less mobile pollinator species. Journal of Applied Ecology 52:602-610.

Koski MH, Meindl GA, Arceo-Gómez G, Wolowski M, LeCroy KA, Ashman TL (2015) Plant-flower visitor networks in a serpentine metacommunity: assessing traits associated with keystone plant species. Arthropod-Plant Interactions 9:9-2I.

LaBar T, Campbell C, Yang S, Albert R, Shea K (2014) Restoration of plant-pollinator interaction networks via species translocation. Theoretical Ecology 7:209-220.

Landis TD (2014) Monarch waystations: propagating native plants to create travel corridors for migrating monarch butterflies. Native Plants Journal I5:5-16.

MacGregor CJ, Pocock MJ, Fox R, Evans DM (2015) Pollination by nocturnal Lepidoptera, and the effects of light pollution: a review. Ecological Entomology 40:187-198.

MacLeod M, Genung MA, Ascher JS and Winfree R (2016) Measuring partner choice in plant-pollinator networks: using null models to separate rewiring and fidelity from chance. Ecology 97:2925-2931.

Mader E, Shepard M, Vaughan M, Hoffman Black S, LeBuhn G (20II) Attracting native pollinators: Protecting North America's bees and butterflies. The Xerces Society, North Adams, Massachusetts.

Mayfield MM, Bonser SP, Morgan JW, Aubin I, McNamara S, Vesk PA (2010) What does species richness tell us about functional trait diversity? Predictions and evidence for responses of species and functional trait diversity to land-use change. Global Ecology and Biogeography I9:423-43I.

Medan D, Basilio AM, Devoto M, Bartoloni NJ, Torretta JP, Petanidou T (2006) Measuring generalization and connectance in temperate, year-long active systems. In: Waser N, Ollerton J (eds) Plant-pollinator interactions: from specialization to generalization. University of Chicago Press, Chicago, Illinois, pP 245-259. 
Memmott J, Waser NM, Price MV (2004) Tolerance of pollination networks to species extinctions. Proceedings of the Royal Society of London Series B: Biological Sciences 27I:260526II.

Menz MH, Phillips RD, Winfree R, Kreme C, Aizen MA, Johnson SD, Dixon KW (20II) Reconnecting plants and pollinators: challenges in the restoration of pollination mutualisms. Trends in Plant Science I6:4-12.

M'Gonigle LK, Ponisio LC, Cutler K, Kremen C (2015) Habitat restoration promotes pollinator persistence and colonization in intensively managed agriculture. Ecological Applications 25:I557-I565.

Montoya D, Rogers L, Memmott J (2012) Emerging perspectives in the restoration of biodiversity-based ecosystem services. Trends in Ecology and Evolution 27:666-672.

NPSS (Native Plant Society of Saskatchewan) (2013) Native plant material and services supplier list [online] URL: http://www.npss.sk.ca/docs/2_pdf/Native_Plant_Source_List_ 2013_-_revised.pdf (accessed 28 September 2016).

Parachnowitsch AL, Elle E (2005) Insect visitation to wildflowers in the endangered Garry Oak, Quercus gartyana, ecosystem of British Columbia. The Canadian Field Naturalist I 19:245-253.

Robson DB (2008) The structure of the flower-insect visitor system in tall-grass prairie. Botany 86:1226-I278.

Robson DB (2013) An assessment of the potential for pollination facilitation of a rare plants by common plants: Symphyotrichum sericeum (Asteraceae) as a case study. Botany 91:34-42.
Russo L, DeBarros N, Yang S, Shea K, Mortensen D (2013) Supporting crop pollinators with floral resources: network-based phenological matching. Ecology and Evolution 3:3I25-3I40.

Saavedra S, Stouffer DB, Uzzi B, Bascompte J (20II) Strong contributors to network persistence are the most vulnerable to extinction. Nature 478:233-235.

Sheffield CS, Frier SD, Dumesh S (20I4) The bees (Hymenoptera: Apoidea, Apiformes) of the Prairie Ecozone, with comparisons to other grasslands of Canada. In: Giberson J, Carcamo HA (eds) Arthropods of Canadian grasslands volume 4: Biodiversity and systematics part 2, Biological Survey of Canada, pp 427-467.

Stang M, Klinkhamer PG, Van Der Meijden E (2006) Size constraints and flower abundance determine the number of interactions in a plant-flower visitor web. Oikos II2:I I I-I2I.

Tarrant S, Ollerton J, Rahman ML, Tarrant J McCollin D (2012) Grassland restoration on landfill sites in the east midlands, United Kingdom: an evaluation of floral resources and pollinating insects. Restoration Ecology 2I:560-568.

Thorpe AS, Stanley AG (20II) Determining appropriate goals for restoration of imperilled communities and species. Journal of Applied Ecology 48:275-279.

Trottier GC (1986) Disruption of rough fescue, Festuca hallii, grassland by livestock grazing in Riding Mountain National Park, Manitoba. Canadian Field-Naturalist I00:488-495.

Wilkerson ML, Ward KL, Williams NM, Ullmann KS, Young TP (2014) Diminishing returns from higher density restoration seedings suggest trade-offs in pollinator seed mixes. Restoration Ecology 22:782-789. 